\title{
臓器鉄游出に関する研究 各種鉄剤負荷肝藏よりの鉄游出の難易に就て
}

\author{
日本医科大学栄鹤学教室（主任 島田敏夫教授） \\ 立川高 汎 \\ Takahiro Tachikawa
}

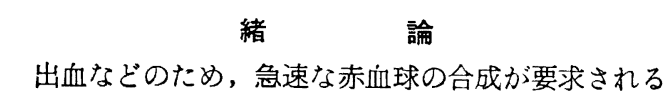
と,藏器殊に肝臟から鉄の游出が起り,てれにてたえる ととは采知の事実である。然しての際藏器はどの様な 規約の下に鉄の放出を行なうものなのかについては従 来屡々論ぜられたが明瞭とは云えない。最近協同研究 者，名和名 は肝藏潅流法を用いて鉄游出を招く因子に 就いて詳細な検討を加えた結果, その出動機序は極め て複雑で一元的に説明するてとは到底出来ないと述へ ている。生体に於いては更に神経の Hormon ${ }^{2)}$ の作 用がてれと関連をもつであろうから一層複雑化してい るととが予想される。

通常藏器貯藏鉄と血清鉄の間には量的平衡関係が成 立していると考えられるが細胞膜の通過性は 3 価鉄よ りも2 価鉄の方に有利 ${ }^{3}$ であるととを考虑すると，そ

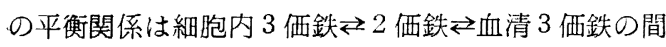
の平衡とおきかえて考えるととが出来る゙。事実この 平衡に移動が起きると想われる種々の条件を負荷する と鉄の組織への移動又は游出が起るととは著者等の一 連の研究で明らかとなつた

鉄游出は更江細胞膜の透過性 ${ }^{5}$, 血清内鉄結合蛋白 質包) 及び藏器蛋白質含有量の多塞等と密接に関係する ととも識られている。

臟器鉄は hemosiderin, ferritin 及び所謂 labile iron から成立つていると言われるが，経口投与によ る鉄吸収量には，一定の制約があるため，その急速な 増加を期待する場合には，種々の非経口的鉄剤が江夫 され臨床的に使用されている。然しそれ等鉄剤の溶存 状態が ion 化するもの或いは colloid 状のもの総べ て同一でないため，投与初期には各鉄肪は各個有の型 で組織に補足されてゆくものと考えられる。

小泉》 は先に ion 化鉄としてクエン酸安門を, colloid 性の鉄として imferon, gluferricon を使用
し, 臓器の捕捉力を詳細に比较検討し鉄の種類により 明らかに瀻器捕捉の速度に相椲のあることを明らかに した。

この様に相違した状㦔で組織に捕捉された鉄が再び 游出する場合には, その游出速度に相違があるかどう かに就いては全く未詳である。勿論鉄投与長時間後に は全て ion 化鉄として絸胞内に摂取され，その出動 も同一速度になるであろうが，極めて初期では必ずし も同一とは考元られない。ての点を予为解明しておく ことは鉄の利用される速さを知ることとなり，実用に 際し，極めて重視されて来る問題と想われる。こてで 著者は小泉の使用したと同様その溶存状態の異なる鉄 剤を予只荷した家鬼の肝藏を種々の条件の下に潅流 して鉄の游出実験を試み，いささか與味ある成績を得 たので報告する次第である。

\section{実験編}

実験動物

1）実験動物は体重 $2 \mathrm{~kg}$ 前後の雄家鬼を用い購入 後 1 力月以上同一飼料で飼育したものである。

2) 肝藏潅流法は明石 ${ }^{11}$, 名和 ${ }^{8)}$ 等の行つたものと 全く同一である。その大略を述べると, 肝動脈, 右腎 静脈を結惄後，門脈より tyrode 液を流入させ肝瀻血 液を洗出した後 100 $120 \mathrm{~mm} \mathrm{H}_{2} \mathrm{O}$ 圧で下大静脈より カニューレを介して潅流する。との際潅流速度は点滴 装置を介して 10 分間 $15 \mathrm{~m} l$ 前後とする。潅流液温度 は $38^{\circ} \mathrm{C}$ とした。潅流液は， 2 槽に盛り一部は tyrode 液のみ, 他は負荷薬剤を混ぜた tyrode 液を入れて自 由に切変え出来る様に装置した。

潅流液の $\mathrm{pH}$ は 7.2 を使用するのが, 最も理想的 であるが，鉄剤使用の関係上 $\mathrm{pH}$ 6.8 6.5 亿調製し た tyrode 液を使用した。

3）鉄測定法は Barkan の変法”によつた。即ち滩流 
$-178-(730)$

採取液 $2 \mathrm{ml}$ 遠沈管にとり，てれに $1.2 \%$ 绵酸 1.0 $\mathrm{m} l$ を加えて, 室温 24 時間放置後 $20 \%$ トリクロー ル醋酸 $1.0 \mathrm{~m} l$ 混和, 1 分間 $3000 \mathrm{rpm}$ で遠沈を行い 沈㴬を除去する。その上清 $1.0 \mathrm{~m} l$ に飽和醋酸ソーダ $0.5 \mathrm{ml}$, 醋酸 buffer (pH 4.5) $0.5 \mathrm{ml}, 0.1 \%$ o-phenanthroline $1.0 \mathrm{~m} l$, thioglycol 酸 1 滴添加後発色さ せ filter $515 \mathrm{~m} \mu て ゙$ photometerにより測定した。 液栺 $1 \mathrm{~cm}, \mathrm{Fe}$ 1r の extinctionは 0.0936 である。

\section{実 験 方 針}

緒論に述へた通り溶存状態の異なる鉄剤を選んで予 め静注し, 負荷鉄が大部分瀻器に捕捉されたと想われ る 1 時間 30 分後 " 潅流実験を行つた。この他に捕 捉状態に影響を及ぼすと考元られる後述の条件を与え た際その游出量を求めたものもある。使用鉄剤は ion 化鉄剤としては，クエン酸鉄安門を， colloid 鉄郕と しては imferon 及び gluferricon (塩野義製品) を使 用した。imferon は血㢣 $\mathrm{pH}$ に於いても極めて安定 であり，長時間にわたり沈澱の恐れがないてとが識ら れているものである ${ }^{10)}$ gluferricon は溶存時 colloid 粒子が比較的大きく組織に沈澱する傾向が大きいもの と考えられるものである。塩化鉄或いは硫酸鉄の様に 鉄 ion として解離するものは極釡易に水酸化鉄と して沈澱すること及びその毒性 ${ }^{11)}$ 考虑に入れて不適 当と考えたために使用しなかった。

各条件を与えた場合の成績を以下順次述べる。通常 鉄負荷量は鉄として prokilo $4.5 \mathrm{mg}$ を $5 \%$ ブドウ 糖 $10 \mathrm{~m} l$ に溶かして極めて緩徐江静脈注射により与 光注射後 1 時間 30 分経つてから肝藏潅流を行つた。

\section{実 験 成 績}

1) Acetylcholine の潅流実験

Acetylcholine は細胞膜の透過性に影響する薬剤と 考元られ，その增加は細胞膜の透過性を増すと云はれ ている。生体実験では肝臟から鉄の游出を促進し, 又 潅流実験によつても増加するてとが，名和 ${ }^{8) 12}$ によつ て既に認められている。殊に名和の潅流実験によると その增加は連続的でなく, 40 分後に一時的な余り多 量でない鉄の游出を起すととか報告され，乙の游出鉄 は細胞内にある極めて labile な鉄が出動するためと 推定している。

溶存状態の異なる前記 3 種類の鉄刘を目荷した後， acetylcholine を $50 \mathrm{mg} \%$ の割合に流した成績は, 第 2 図に示した通りである。第 1 図は tyrode 液単独 潅流成縜である。

i) FeAC $4.5 \mathrm{mg} / \mathrm{kg}$ 負荷では第 2 図中 a) の曲線

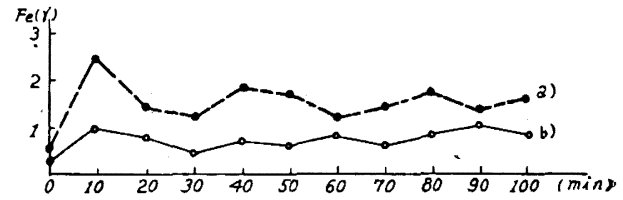

a) 游出総量 (16.5 r)

b) " (7.7 $\gamma$ )

第 1 図正常肝臓の ty rode 液単独潅流実験

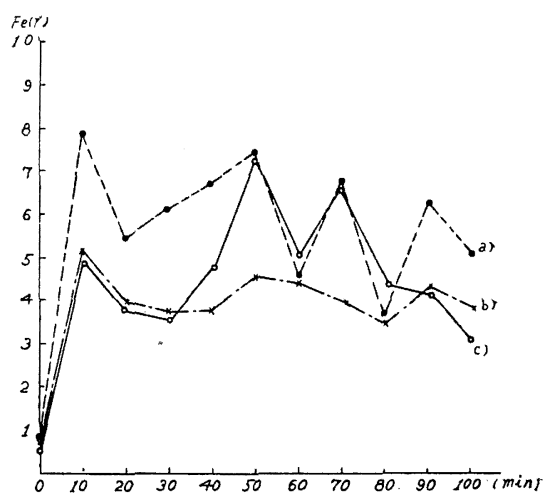

(a) FeAC (游出総量 $68.7 \gamma$ )

(b) gluferricon (41.4 $\gamma$ )

(c) imferon (47.2 r)

条件 : acetylcholine $50 \mathrm{mg} \%$ 各種負荷鉄 $4.5 \mathrm{mg}(\mathrm{Fe}) / \mathrm{kg}$ $\mathrm{pH} 6.5$

第2图 acetylcholine 潅流実験

の様に游出鉄は初期に急激な增加を喼め次第に低下し てゆく, 一時的に 40 分前後で游出が起ると報告する 名和らの成績とは異なるがてれは鉄負荷に因るものと 思われる。

游出鉄量には相当の動摇を認めているが，総游出鉄 量は 68.7 rで, tyrode 液だけを流した場合に較べる と多い。名和 ${ }^{8}$, 山下 $\left.{ }^{13}\right)$ の言う様に labile 鉄に由来す るとすれば，鉄負荷により肝蔵総鉄量の增加に伴い labile 鉄も增すであらうから，その游出增加とも考元 られる。

ii) imferon. gluferricon 各 $4.5 \mathrm{mg} / \mathrm{kg}$ 負荷例は 図中 b）c）に示した様に imferon は 50 分前後で一 過性の上昇があり gluferriconは極めて緩かな山型曲 線を示した。各実験例により流出総鉄量に相違はある が, imferon は平均 $47.2 r$ gluferricon は平均 41.4 . てであつた。FeAC が最も多く imferon はててれに 次ぎ, glufericon の場合は稍々劣るととが識れた。

2) Histamine の潅流実験（第 3 図 i) ii))

histamine $z$ acetylcholine 同様正常動物の肝貯蔵: 


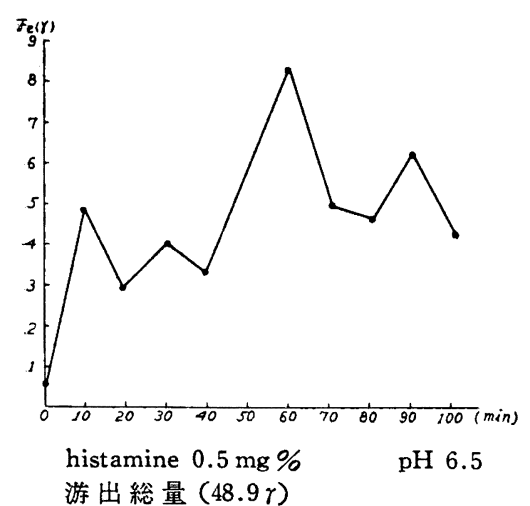

游出総量 $(48.9 \gamma)$

第3図 (i) Histamine 潅流実験

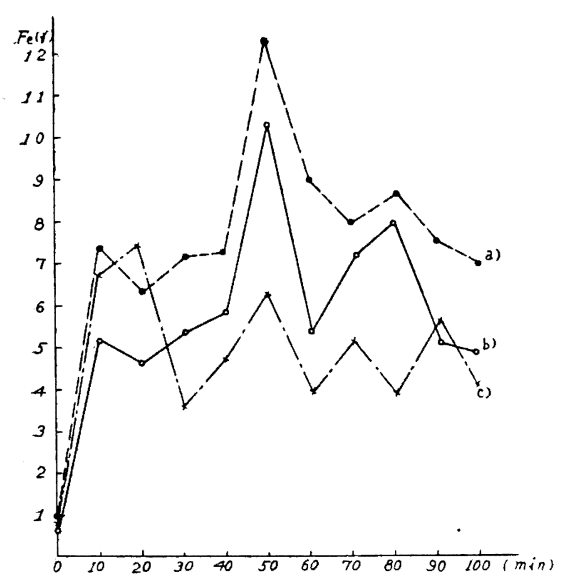

a) $\mathrm{FeAC}$ 游出総量 $(81.1 \gamma)$

b) imferon (61.9r)

c) gluferricon (52.3 $r$ )

histamine $\quad 0.5 \mathrm{mg} \%$

各種負荷鉄 $\quad 4.5 \mathrm{mg}(\mathrm{Fe}) / \mathrm{kg}$ $\mathrm{pH} 6.5$

第 3 図 ii）各種鉄刻負荷後 Histamine で潅流した場合

鉄の出動を促すことが識られている ${ }^{112)}$ 。正常肝㵶 を histamine $0.5 \mathrm{mg} \%$ 加 tyrode 液で潅流すると acetylcholine $50 \mathrm{mg} \%$ の場合に較べて稍々游出鉄量 は大きいと云うが”，第 3 図 i）の様に histamine 単 独潅流では, 平均 43.9 r $/ 100 \mathrm{~min}$ の鉄游出を認めた。 3 種の被鉄負荷肝蔵に histamine を潅流した場合の 成績では FeAC が最も高值を示し(81.1 r), imferon, gluferricon とつつく, やはり acetylcholine 単独に 較べると稍々游出が多い様である。3 者の鉄剤のうち FeAC の $81.1 r$ 亿対し後 2 者は共に $61.9 r, 32.3 r$ の鉄游出量である。histamine 潅流では 50 分前後に 一時的な増加が起ることが示されている。

この 2 種類の実験成績から細胞膜の透過性を変える
と, 藏器鉄の溶存状態が異なると想われる場合, 即, ion 化鉄負荷の場合には游出量が增加するか, colloid 鉄製剤は, その游出鉄の増加が劣るととが認められ る。然し imferon, gluferricon の相違については, この成績のみから確実なととは云い難いかも知れな い。

3）鉄と Chelate を造る薬剤を潅流した場合

chelate 試薬, 例えば $\mathrm{EDTA}^{14), 1)} o$-phenanthorolime, $\alpha-\alpha^{\prime}$-dipyridyle 等を静注投与すると藏器の鉄 は溶性となり，腎を通じて排泄されるととはよく知ら れている。特に臨床上重金属の体外排泄に効果がある と云う ${ }^{15)}$ EDTA は名和の潅流成績によると100〜 $300 \mathrm{mg}$ \% と濃度の差があつても, 流出鉄には余り相 違がなと云うので EDTA $100 \mathrm{mg} \%$ を各鉄剤負荷 後潅流しその際の鉄の游出を観察した。FeAC の場 合は第 4 図a)の様に実験時間中に $82.8 r$ の鉄游出が 起つている。gluferricon 負荷動物の潅流は第 4 図 b)

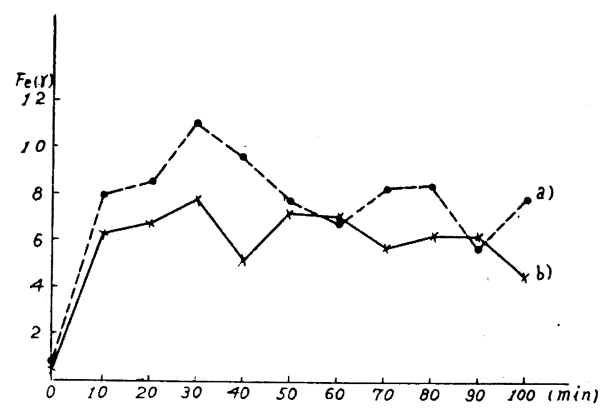

a) $\mathrm{FeAC}$ 游出総量 $(82.8 \gamma)$

b) gluferricon $(65.8 \gamma)$

EDTA $100 \mathrm{mg} \%$

負荷鉄 $4.5 \mathrm{mg}(\mathrm{Fe}) / \mathrm{kg}$ $\mathrm{pH} 6.5$

第 4 困 鉄負荷後の EDTA 潅流実験

曲線で游出鉄は 65.8 となつた。FeAC 負荷例に較 べて稍々劣り, 約 77\% となつている。てれらの差は 余り著明とは云い難いが FeAC 例が gluferricon 例 より各実験例ともつねに上迴つて游出することは確実 であつた。

てれは EDTA の結合が ion 反応であるため FeAC とは容易であるが, colloid 鉄とはその結合反応が遅 いために游出が劣るとも想われる。之等 chelating agent を潅流した場合は，その経過曲線型が細胞膜透 過性を変えた場合の実験と異なることは興味がある。 $o$-phenanthroline 潅流実験

成績は EDTA と全く同一と云える。(図略)とれ 等 chelate 試薬に関する $2 つ$ 実験から imferon, 


$$
-180-(732)
$$

gluferricon の様に colloid 状態のものでは，その結 合力が微弱であるため游出量が稍々劣るものと想わ れ肝蔵に捕捉されている負荷鉄が，それぞれ異なつた 状態で存在するてとを示唆しているものと考えられ る。

\section{還元剂使用実験}

i）正常動物肝臟を ascorbin 酸混和 tyrode 液で 潅流した場合の成䋶

還元剤として ascorbin 酸を選んだ。還元剤は作用 させる medium の $\mathrm{pH}$ の差により, その還元能力 に大きな差を示すととは，第 5 図 i）ii)汃ら明らかで

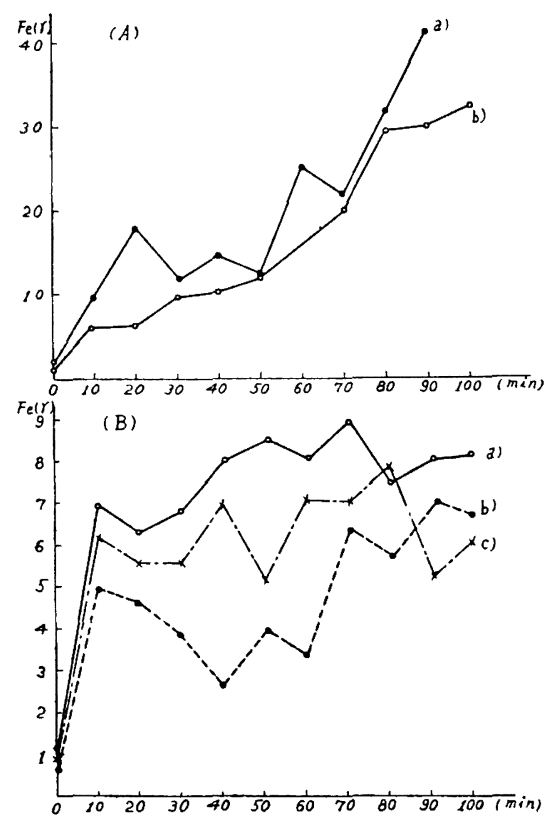
A).a) 游出総量 (190.5r) b) (187.5 r)

Ascorbin 酸 $250 \mathrm{mg} \% \quad \mathrm{pH} 4.5$

B).a) Ascorbin 酸 $250 \mathrm{mg} \%$ 游出総量 (80 r)

b) Ascorbin 酸 $50 \mathrm{mg} \%$ (48.3 $\gamma$ )

c) Ascorbin 酸 $100 \mathrm{mg} \%(64.0 \gamma) 64.0$

第 5 図 i) Ascorbin 酸潅流

あるが生体により近い笔囲で実験すべく以後の実験の 淮流液は, 総べて $\mathrm{pH}$ 6.8 6.5 亿補正した後実験し た。第 5 図にb) 示す様に $50 \mathrm{mg} \%$ ascorbin 酸潅流 では游出量は初期にすでに多量に, 後期は濑增する曲 線を画き, 100 分間の総量は 48.3 rであつた。

$100 \mathrm{mg} \%$ の潅流では総量 64.0 r 游出し $250 \mathrm{mg} \%$ になると稍々増加を招き，総量 $80 r$ となつた。

ii）鉄負荷肝㖑に ascorbin 酸を潅流した実験 鉄 凨は上記 3 種類のものを予め静注し， 1 時間 30 分後 の肝臟について実験した。その成績は第 6 図である。

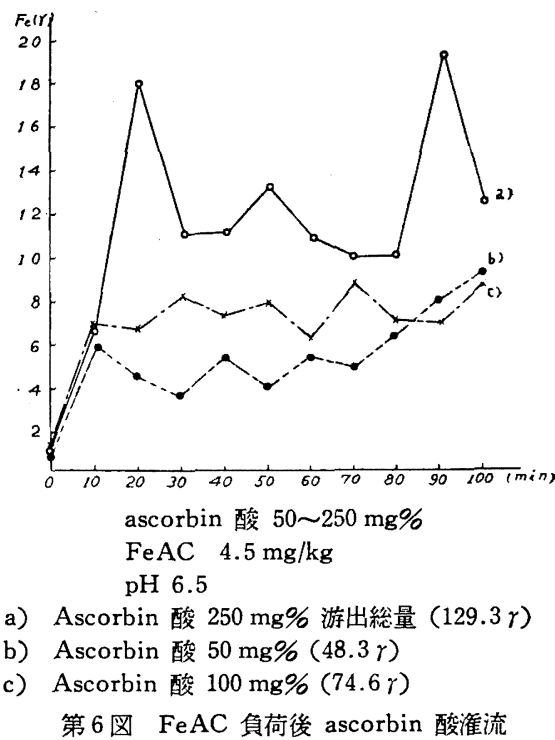

$\mathrm{FeAC}$ 投与肝㵴からは $50,100 \mathrm{mg}$ 及び $250 \mathrm{mg} \%$ と ascorbin 酸量が増すに従い 游出鉄量が增加して来る が $50 \mathrm{mg} \%$ ascorbin 酸投与例では, 総量 $48.3 r$ で鉄 を負荷しないものと殆んど同一であり。鉄負荷の影響 があらわれて来ない。100 $\mathrm{mg} \%$ 亿なると総游出は鉄 量 $74.6 r$ となつて ascorbin 酸単独投与例 $64.0 r$ 亿較 べて稍々增加する傾向がみられた。250 mg に ascorbin 酸を増すと ascorbin 酸単独の場合に較べて明ら かに増大し総鉄量は $129.3 r$ となつた。且つ, 曲線に 初期後期 2 つの峰が画加るる。

imferon 負荷例では第 7 図の様に ascorbin 酸 250

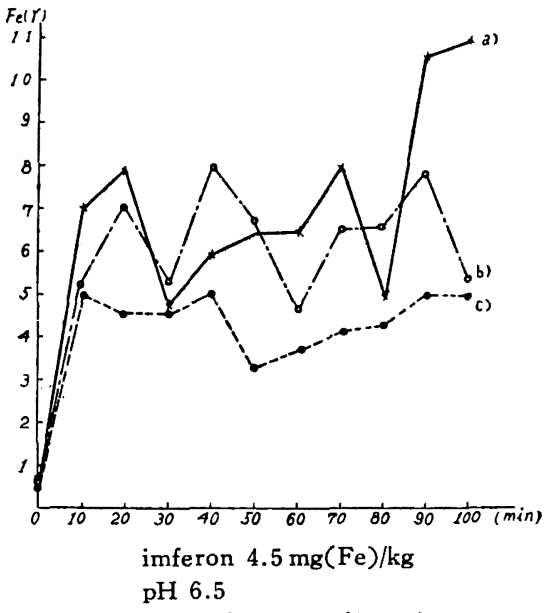

a) Ascorbin 酸 $250 \mathrm{mg}(73.6 \gamma)$

b) Ascorbin 酸 $100 \mathrm{mg} \%(63.4 \gamma)$

c) Ascorbin 酸 $50 \mathrm{mg} \%(46 \gamma)$

第 7 図 Imferon 負荷後 ascorbin 酸潅流 
$\mathrm{mg}$ 流しても鉄の総游出量は $80 r$ 前後で ascorbin 酸 $250 \mathrm{mg}$ 単独投与の場合と殆んど同一であつた。然し 游出曲線型は FeAC 負荷の場合とよく似ている。

gluferricon 例では, 総游出鉄量 $70.5 r$ であまり ascorbin 酸の効果を認めなかつた。次に負荷鉄不足 のため明らかでないてとを考虑して負荷鉄を 5 倍に増 した $22.5 \mathrm{mg} / \mathrm{kg}$ 投与実験を行つた。FeAC 第 8 図 a)の様にその游出鉄量が 250 亿増加したが imferon も第 8 図 b) の様に潅流開始と同時に急速に増し，凡

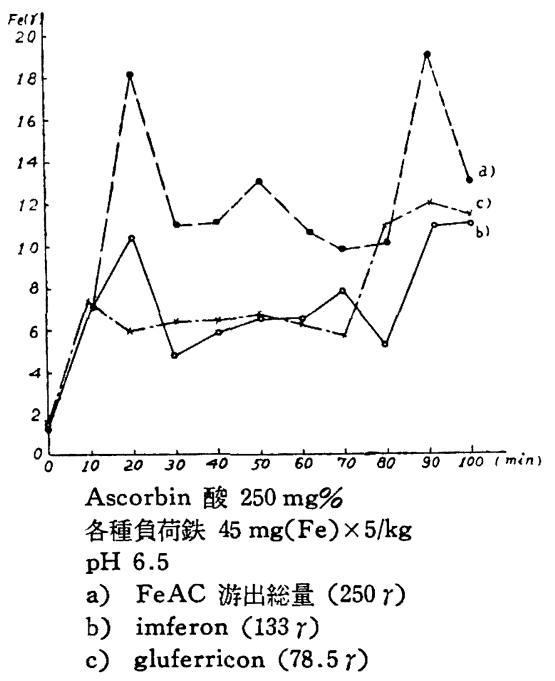

第 8 図各種鉄郕大量負荷後 Ascorbin 酸潅流

そ 30 分後に再び急激に減少する曲線を示し, 総鉄量

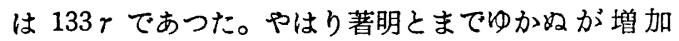
した。 gluferricon の場合は前 2 者と異なり $78.5 \tau$ 前後で投与鉄の增大に関らず僅か増加の傾向に止まつ た。

負荷鉄增量に伴つて増加したとは云え, FeAC 群 と imferon, gluferricon 群とは明らかに游出量が相 違しているととが解る。この ascorbin 酸の実験成績 からも，組織に捕捉される鉄の状態は明らかに晎なる こと,即ち, FeAC は主として ion 化し易い鉄として あるため容易に還元され, imferon 及び gluferricon は未だ colloid の状態の儘存在する為還元され難いこ とが推知出来る。

\section{Cortisone 投与実験}

副腎皮質 hormon である cortisone は網内系細胞 を活性化して鉄の摂取を增加すると云われる。乙れに 関する研究は, 最近横瀬 ${ }^{16)}$, R.C. Crafts ${ }^{17)}$ らによつ て報告確認されている。網内系細胞によつて攝取され るものは主として colloid の性状を持つものであり， ion 化物質は実質細胞に取り入れられると信じられて いる。従つて本実験に使用する鉄剂もそれぞれ性質の 相異により異なつた細胞に摂取されるので, 游出に際 しては異なつた態度を示すととが推定される。こてで cortisone を予め投与し網内系細胞を活性化し次で鉄 剤を負荷して充分鉄を摂取させた後 ascorbin 酸によ る鉄の游出がどの様に変るかを追究しだ。

cortisone は $25 \mathrm{mg} \times 5$ を皮下注射し，その最も効 果が著明である 4 時間後に鉄を負荷し, 更に, その後 1 時間 30 分経つた肝藏について実験を行つた。この 際効果の判定を容易にするため 負荷鉄は $22.5 \mathrm{mg} の$ 多量を用いて行つた。成績は第 9 図である。

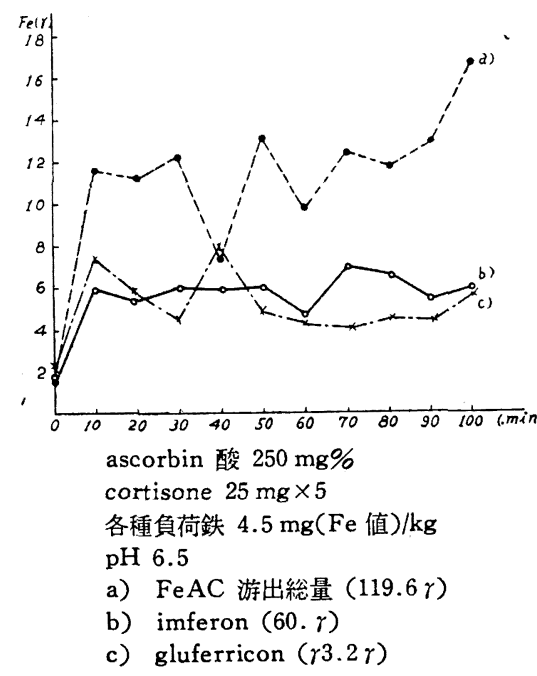

第9図Ascorbin 酸の鉄游出勃果に及ほす Cortisone の影響

$\mathrm{FeAC}$ は第 9 図a）曲線の様な線過をとろがその游 出総鉄量は $119.6 r$ である。imferon 負荷の場合は b) 曲線で総游出量は $60.7 r$ であつだ。gluferricon 投 与曲線 c) では $53.2 r$ と imferon 負荷に較べて稍々 游出量が少ないようであつた。

この成績から cortisone によつて網内系細胞を活性 化すると gluferricon, imferon 共に ascorbin 酸によ る游出が制約されるととが解つた。

Adrenaline 潅流実験

末梢血管を収縮する adrenaline を投与した際の鉄 游出状沿を観察した。adrenaline は $1 \mathrm{mg} \%$ とし連続 投与を行なつた。この際潅流液が血管の縮少によつて 僅に減少するので, 潅流液の圧を調節して正常量を保 つ様心掛けた。

正常肝藏の場合は第 10 図 c) 曲線に示す通り潅流 


$$
-182-(732)
$$

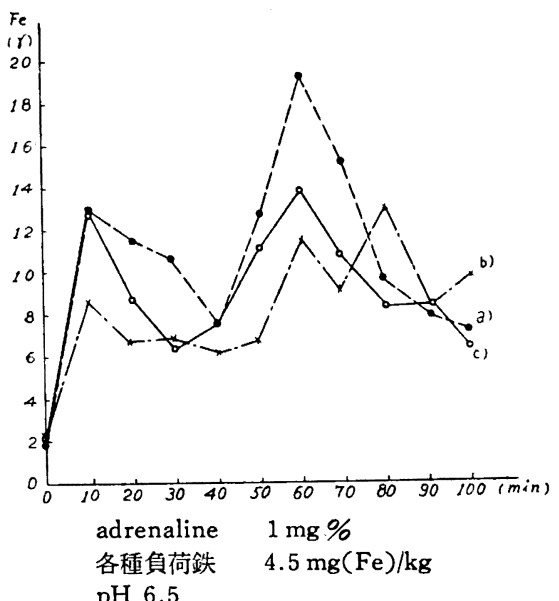

a) $\mathrm{FeAC}(115.3 \gamma)$

b) gluferricon 游出総量 $(90.8 \gamma)$

c) adrenaline のみ $(94.5 \gamma)$

第 10 図 各種鉄剂負荷後に Adrenaline を潅流し た成績

が進むに従い，一時降下した鉄游出は再び増加し 60 分を境として再度减少する。然し正常肝藏 tyrode 液 のみの潅流に 比較すれば adrenaline の作用によつて 著名に増加を招いていた。

$\mathrm{FeAC} 4.5 \mathrm{mg} / \mathrm{kg}$ 負荷動物肝蔵の adrenaline 潅流 の場合は a) 曲線の様に adrenaline 単独投与の場合 と全く同型の経過を示しているが総鉄游出量が稍々多 い。

gluferricon を $4.5 \mathrm{mg} / \mathrm{kg}$ 負荷例では曲線 b) の様 に, 全体としてみれば前実験と同一の経過であるが游 出鉄量は adrenaline-tyrode 液学独潅流に較べて僅 かながら少ない様に思われる。然し少くとも FeAC 負荷例に対しては，その游出鉄量の減少は確実浔め られた。実験の始めにてれら鉄剤の溶存型体から推し て adrenaline の投与により細狍内に深く浸入してい る鉄は余り影響を受けずむしろ末梢血管に沈着してい 万 colloid 性の鉄及び網内系捕捉鉄の一部が血管の縮 少のためわし出され，游出鉄の增加を招くであろうと 期待したが全く逆の成績が得られた。ての成績から判 断すると colloid 性の鉄は血管縮少によつて更に流動 し難くなり，より狭小の部分に押込められ，游出の主 体はむしろ従来加考えている細胞内 labile 鉄であ り，てれが adrenaline の作用で押出されるととを示 すものと想われる。

Sprase (Hyaluronidase) 投与実験

拡散因子として広く識られている sprase の鉄游出 に及ぼす影響を榙べた。采知の通りD. Reynald が見
出した hyaluronidase は結合組織の基質をなしてい る hyaluron 酸を水解して基貿の粘稠性を急速に減 じ組織内での液体の拡散を容易にするもので, 所謂 組織の淕性又は通過性を良好にすると云われて ${ }^{18)}$, acetylcholine 或いは, histamine 等の細胞膜の淩透 性を変えるものとは, その作用機構が異なる。この拡 散因子を用いて游出の態度の変化を観察した。

第 11 図 i） ii）はその成績である。 sprase の使用 量は 4,000 unit 及び 8,000 unit を潅流液 $250 \mathrm{~m} l$ 中 に溶解させたものである。第 11 図 i）a）及びb)に みる様に何れも tyrode 液のみの場合に 較べて著名な 増加が起る。醉素湌度の相違は鉄游出に余り影響を認 めない。とのととは sprase 8,000 unit を直接門脈に 注入した場合も游出量は殆んど同一であるととから解 る。予め $\mathrm{FeAC}$ を $\mathrm{Fe}$ として $4.5 \mathrm{mg} / \mathrm{kg}$ 負荷した

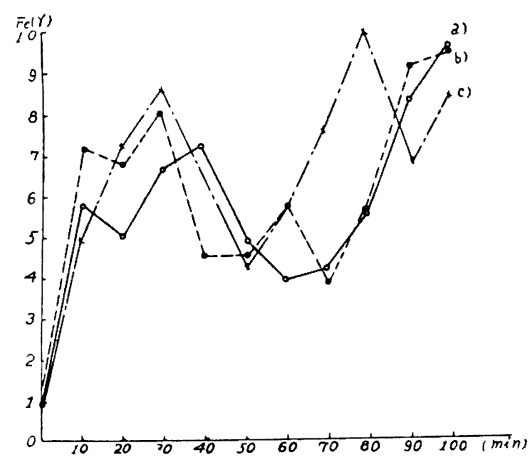

a) Sprase $(4,000 \mathrm{u})$ 游出総量 $60 \gamma$

b) Sprase $(4,000 u) 63 \gamma$

c) Sprase $(8,000 u) 77.5 \gamma$

第 11 図i） Spraseによる潅流

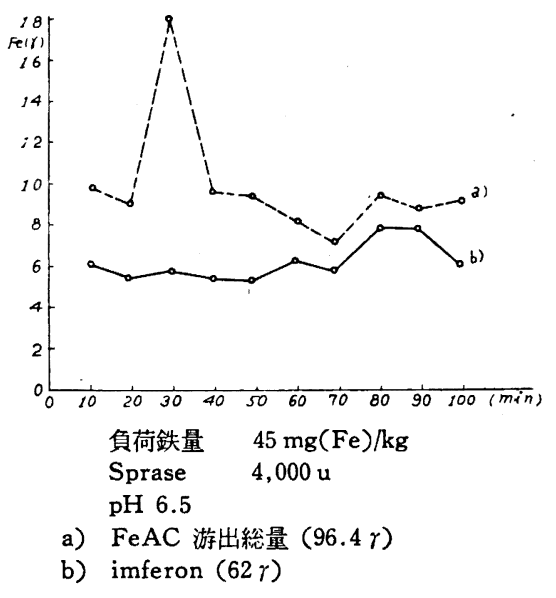

第 11 図 ii) FeAC, Imferon 負荷後に Sprase て 潅流した成續 
家鬼肝では，第 11 図 ii) a) の如く游出量が著しく sprase 投与 30 分後峰をもつて増加する。ての曲線 型からみると組織間隙に蓄積していた鉄が sprase の 作用によつて細胞間隙の緊張がとれ游出を招いた様に 思われる。実験後半期の流出増加の理由の解噃は因難 だが，或いは細胞個体に含有されている鉄によるもの で負荷の有無に関係がないのではなからうかと思われ る。

imferon の場合は 11 図 ii) b) の様に sprase 単 独䝘与の場合と殆んど同様であつた。

gluferricon 負荷例では第 11 図 iii) の如く一例は

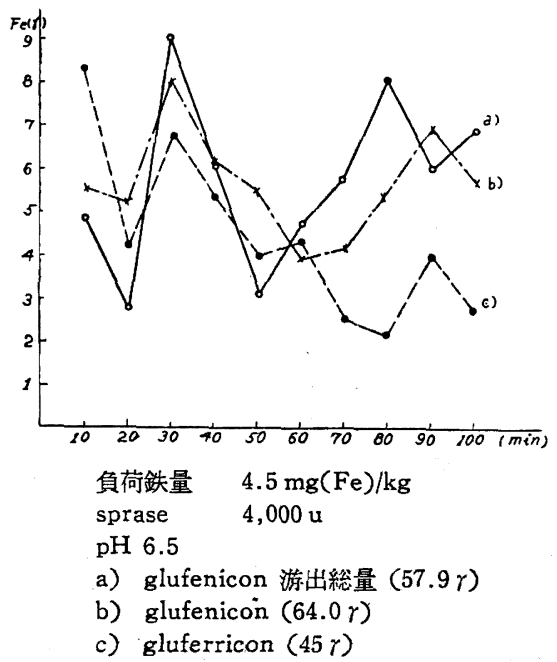

第 11 図 iii) gluferricon 負荷後に sprase で潅 流した成績

極めて初期の流出は認めるが次第に減少し，その游出 総量は $45 r$ であうたが，その他 2 例では曲線に示す 通りそれぞれ $57.9 r ， 6,450 r$ と稍々游出鉄量が増す。 その曲線型及び鉄量は sprase のみ流したものと殆ん ど同じであつた。

cortisone で鉄の捕捉が増加した肝臟に sprase を 投与した実験

先の実験により colloid 性鉄剂は cortisone の投与 により肝臟に強く保留されて tyrode, ascorbin 酸潅 流による游出に対して抵抗するてとを識つたが，ての 状態の肝臟化 sprase を作用させてみた成績は第 12 図である。乙の結果は極めて興味あるもので，FeAC 負荷検体游出曲線型は a）a） b) の如くであるが，総 鉄量は $160 r, 125 r$ で平均 $143.5 r$ と多量の鉄流出 が起つている。

cortisone 非投与群に及ぼす sprase の効果より稍

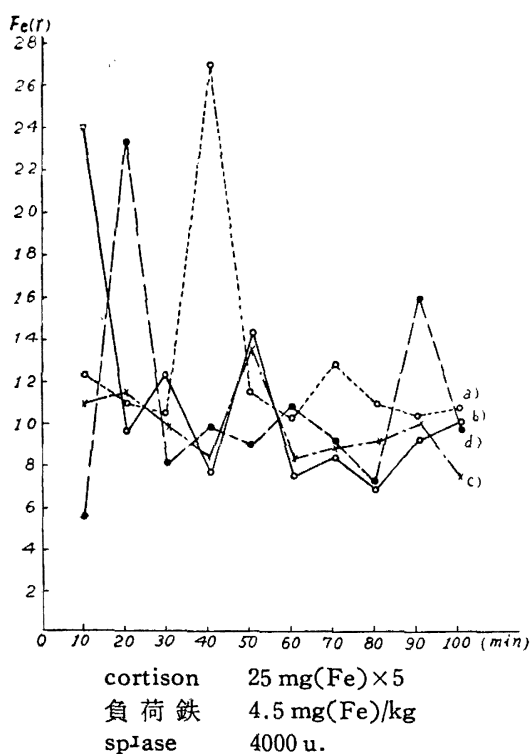

a) $\mathrm{FeAC}$ 游出総量 $(160 \gamma)$

b) imferon (111.5 r)

c) gluferricon $(106 \gamma)$

d) $\mathrm{FeAC}(127 \gamma)$

第 12 図 Sprase の鉄游出効果と cortisoneとの 関俰

々增加の傾向を示す。とのととは cortisone によつて 網内系の活性化が起り網内系細胞に摂取される鉄の絶 対量が増加したためとも考えられる。

gluferricon の場合も曲線 C) の様江総鉄量 $106 r$ で明らかに增加した。

\section{考}

按

何等かの理由て臟器の鉄が減少した場合，それを急 速に補うためには，どの様な種類の鉄剤を使用するの が，最も効果的であるかと云う問題は古くから検討さ れたが，今尚新しい課題である。鉄 ion は極めて毒 性が強いため，非経口的投与の場合には，種々鉄剤が 考案されている。即ち，製剤は鉄醋塩として，或いは colloid 鉄として用いられいるが現在でも充分その目 的に沿つたものは無い様である。

小泉は静脈内鉄負荷後の消失速度から真の蔵器の鉄 要求度を識るために種々の鉄剤，例光ば ion 化性鉄

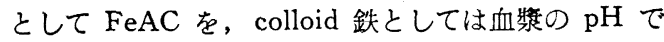
極めて安定な imferon 及び 不安定な gluferriconの 3 種類を使用して研究しているが文，その結果から， $\mathrm{FeAC}$ が最もとの目的に適すると云う。gluferricon は消失速度は最も急速であるが，てれは組織への物理 的沈着によるもので,目的に添わないと報告している。 colloid 鉄の沈着も結極は水解されて 細胞内捕招さ 
れるに到るであろうが，少くとも投与後，一定期間は その儘の状態で存在するととは確かであるから，たと え圧倒的に他の鉄剤に較べて藏器に多量捕捉されたと しても，その短時間内での利用率は極めて低いことに なる。細胞に提取され貯蔵鉄へ転換するには，游離の 鉄 ion の型を経ることは当然であるが，乙の転換の 容易さは負荷鉄の利用度の標尺となり得るから，生理 的条件下で, この速度を予め知ることは極めて重要な ことである。血色素の再成速度から推すことも 1 つの 方法であるが，その生成過程が種々の因子によつて影 響を受けるために鉄そのものの利用度を知るには適当 でないと想われる。

そこで著者は，その手段として肝蔵潅流法の応用を 試みた。即溶存状態の異なる 3 種類の鉄剤を子め負荷 した後, 種々の鉄游出を促す条件を与えて, その際潅 流液に出現する鉄量を比較することにより負荷鉄剤の 効率を識ろうとしたのである。

使用鉄剤は小泉に準し ion 化鉄としては FeAC を， 安定 colloid 鉄剤は imferon. 不安定な colloid 鉄と しては gluferricon を使用した。

実験によつて得られた多様な結果を解析して効率の 良否を比較する場合に，乙れら溶存状態の異なる鉄風 がどの様な状態で組織に捕捉されているかを予め承知 して置く必要がある。従来ion 化鉄剤は実質細胞に colloid 性の鉄は網内系細胞に捸取されると云われ，

事実組織学的の所見はそれを明確に珰めている。

肝藏の組織学的な構造を考えてみると血流は肝動脈 を通して訮㖑に入るが末梢に於いて門脈血流と合して sinusoid を形成して肝臓 lobus を通つた後中心静脈 に集つて vena cava sup. に入る。 sinusoid と肝細胞 群との間には, 所謂 perisinusoid space を形成し組 織液で満されている。これは lymph に通しるわけで ある。肝 lobus を通る sinusoidの一部のものは, 末 梢動脈との連絡がないもので, 所謂 venous sinusoid 又は arteial sinusoid と呼ばれるものもある。

末梢毛細管は門脈に較べてその内容は狭少である (第 13 図 $1 \sim 2$ 参照)

sinusoid の管壁は特殊の構造及び機能を 持ち通常 の静脈血管とは著しく異なつている。殊に，その内壁 には kupper 細胞が多数散在し, その突起により互に 網状に連絡している事は衆知のととである。

sinusoid 壁はその透過性が大きい特長を持ち血清 蛋白質も通過し得るものと云われている。しかしなが ら鉄は蛋白沈海凨として作用すること及び血清の $\mathrm{pH}$

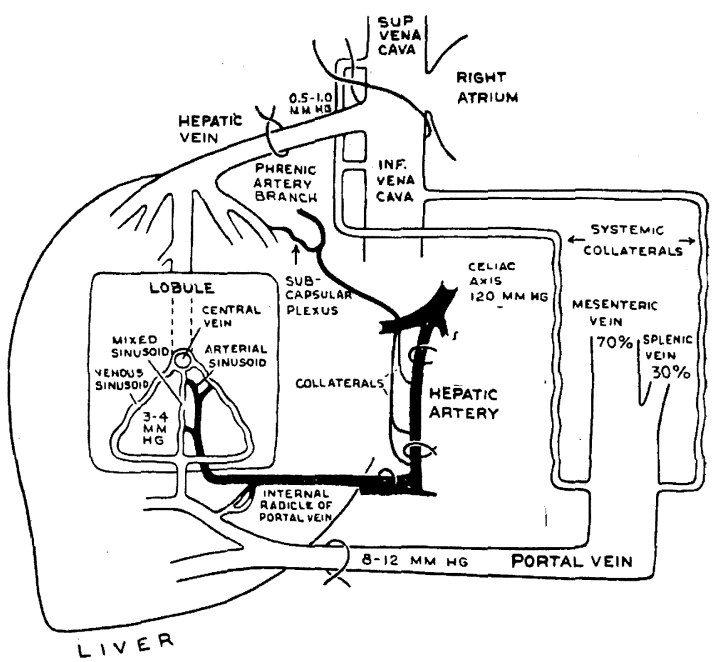

第 13 図(1)

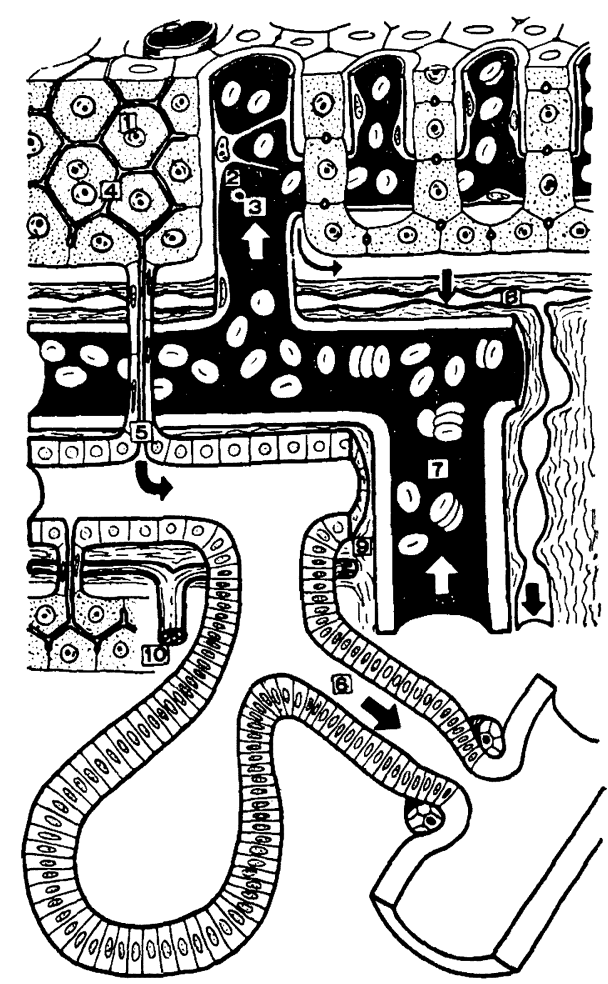

H. Popper and A. Schaffner : Liver : Structur and Function より引用 (The Blakiston Diviation Mc Graw-Hill Book company. Inc. N.Y. 1957 p 7, 140)

第 13 図 (2)

に於いては容易に分子の大きな沈澱物を形成するであ ろうからもしも極めて容易に沈澱する鉄剂が動脈より 
搬入されれば,末佾血管の部で沈着すると同時に vena portae と混合した後 sinusoid に移り，ての部分に沈 殸するか, 又は kupper 細跑に喰食される。乙れ 対し非沈着性の ion 化鉄剤は sinusoid 膜を通過して perisinnsoid space に移動し更に細胞実質に摂取され るであろうと思われる。

てれらの推察が正しいかどうかを解明すべく透過性 を変化させる薬㓮を用い, 且前記性状の異なる 3 種の 鉄剤を用いて検討した。即ち, 各 3 種鉄剤を負荷した 後, 細胞膜の透過性を穴進すると云う acetylcholine 及び histamine を流すと游出鉄は約 30 分に峰を持つ 增加が起る。ての際 FeAC が imferon 並びに gluferricon にくらべて, 稍々多い様に思つて差支えない 結果であつた。最も, 膜の透過性に関係するものは, sinusoid 膜並びに肝細胞膜であろうが，先ず perisinnsoid space 中のクエン酸 ion 鉄が游出して来る ものと推定出来る。

同時に肝細胞内にある游離 $\mathrm{Fe}^{++}$も出動を起すであ ろう。てれ等の鉄量は恐らく $\mathrm{FeAC}$ 投与群が最も多 く imferon がこれに次ぎ gluferricon 群では僅少 と考元られる，従つて潅流に上る鉄の流出量は，ての 順序に差が認められると考えたが, 然し実際には, gluferricon と imferon との間には, それ程著明な差 がなかつた。てれは後 2 者では space 中に蓄えられ る鉄量自体にそれ程大きな差がないものか, 或いは実 駼法が不鋭敏のために相違を認められないか何れかで あろう。

然し，一時的の鉄流出が起るととを考えると space 及び細胞中の蓄積鉄の游出を想わしめる。名和が細胞 内にある labile 鉄の游出と考えたととと一致する。

鉄と強力な結合力を持ち錯塩を作る EDTA 及び $o$-phenanthroline を用いた場合も perisinusoid 或い は実質細胞中の鉄が游出するもので，colloid 性の鉄 凨が出動しにくいのは錯塩形成が容易でないためと考 えられる。

次に僈元戍を潅流した場合の成績をみると ascor一 bin 酸整度の増加に伴い流出鉄量が増して来た。ての ことは組織内鉄が還元に伴つて游出することを物語 る。FeAC が最も著明で imferon 及び gluferricon がてれに次ぐ。ascorbin 酸 $250 \mathrm{mg} \%$, 負荷鉄 22.5 $\mathrm{mg} / \mathrm{kg}$ の多量投与の際は FeAC 及び imferon の実 験例では鉄游出が潅流直後と 80 分前後と二度認めら れたが，乙の初期の游出が perisinusoid space の鉄 及び実質細胞中の lable 鉄が還元されたものか, 或い
は kupper 絊胞に摂取された鉄が出たものかは予断を 許さない。

然し gluferricon が極めて沈着し易いため perisinusoid space には入り難いと思われるとと, 且還元に よつてその初期の增加を認めなかつた実験成績から考 えると FeAC 及び imferon 例の初期增加は, むし ろ perisinusoid 又は実質細狍中の鉄によるものと考 えた方がよいかも知れない。又 perisinusoid spaceの 鉄又は実質緗胞内の鉄の方が， kupper 細胞内に視ら れる colloid 性の鉄の型上り容易に還元されるで あろうととは考元られるので前述の推定に有利であ る。

次に adrenaline 投与実験について考元ると，従来 adrenaline は末瑺血管の血流の增加を招くことはよ く知られている。然し急速な静注又は腹腔内投与で, 反つて減少を招き”，又潅流実験で肝㶓が anoxia 亿 傾く状態では, 正常の場合と異なつた反応性を招くと 云われている ${ }^{20)}$ 。 sinusoid は spranchnic arteries よ りも adrenaline に対して, 反応性は弱いと云われる が注著者の実験では明らかに潅流液の減少を認めてい る。従つて adrenaline 潅流は僅かながら圧を調節し て潅流液量を同一にする样にしたわけである。正常動 物肝臟を adrenaline 加 tyrode 液で潅流すると, 直 ちに一過性の明らかな鉄の游出が起るが，また面ちに 减じその後 40〜60 分を峰として初期の增加を上廻る 著しい出動を認めた。生体に adrenaline を投与する と, 常に投与初期血清鉄の増加を彗めるとととよく一 致する(4)。

生体の場合はその後直ちに急速な低下を招くが, こ れは adrenaline による cortisonの分泌增加が起り 網内系の鉄攝取が元進したためによるものと思われ $3^{22)}$ 。本実験群の游出鉄の機作については充分説明し 難いが arterial sinusoid の収縮並びに perisinusoid space の圧縮等によつて放出が起るためと思われる。

FeAC の目荷家兔の肝蔵の場合は adrenaline 単独 投与の游出曲線之極めて類似する、游出は多少增す が, 特に著しく增加するとは云い難い。これは網内系 細胞の鉄及び肝細胞中の眝蔵鉄は関与せずに末梢血管 及び perisinusoid 中に含まれる鉄のみが游出するた めであろうととを思わせる。

imferon 及び gluferricon 負荷では adrenaline 単 独投与の対照に比べて殆んど大差なく，むしろ減少の 傾向があると云える。てれら鉄剂が沈着又は網内系細 胞に捕捉されたとすれば，血管の縮少によつてょり流 


$$
-186-(738)
$$

出が困難になつたかもしれない。

cortisone 投与実験成績は又興味ある結果を得た。 既に述べた様に cortisone は網内系細胞を活性化して 鉄の摄取を增強すると云われるが， cortisone を投与 後その作用が最も強い時期， $4 \sim 5$ 時間後に 3 種類の 鉄剤を負荷し，更に 1 時間 30 分後に肝蔵潅流を還元 剂添加の下に行うと colloid 性鉄投与群では游出の增 加が著明でない。これは活性 kupper 細胞に捸り入れ られた場合は ascorbin 酸によつて還元速度がにぶく なるためと考えなければ説明がつかない。

次に space を単独に潅流した場合 tyrode 液単独の ものに較べて明らかに游出鉄量の增加が起つて来た。 又, 鉄剂負荷後の肝蔵を sprase て潅流すると夫々の 鉄非負荷例に較べて游出鉄量が増加したが，その割合 は FeAC が最も多く imferon, gluferricon では, 明 瞭でなかつた。とてろが cortisone を投与した後，鉄 を負荷した家鬼の肝藏について sprase を潅流してみ ると明らかに何れの鉄剤負荷例でも游出鉄量の增加 をみた。との両者の矛盾についてはよく解らないが cortisone が網内系以外飞も作用を持つものか, 又 sprace か何等かの道を通して作用し cortisone の網 内系細胞鉄捕捉効果を減弱する為のものかも知れぬ。 然し Fe が sprase の作用を抑制するとと, cortisone も又 sparse の作用を抑制すると報告されるとと等を 考え合わせると，必ずしも満足な説明とは云い難いか も知れない。更に詳細な実験が必要と思われる。

稿を終るに臨み恩師島田教授の御懇篤なる御指導, 御校閲 に深く感謝し，併せて種々御助力を願つた中島信治博士始め
栄養学教室各位並びに神成節子袞の御援助に深謝致します。

女

\section{献}

1）明石敏彦：日本医大誌，26，471 (1956)

2) A.S. Gorden et al : Annal, New York Academy of Science, 52, 31 (1949)

3) 吉野芳夫：生化学誌, 27, 53 (1955)

4）山口文男：日本医大誌，27，1 (1960)

5) P. Saltmann : J. Biol. Chem., 220, 741 (1956).

6) C.E. Rath and C.A. Finch : J. Clin, Invest., 28, 79 (1449).

7）小泉泰孝：日本医大誌，23，70 (1957)

8）名和長昌：日本医大誌，26，462 (1959)

9) G. Barkan : J. Biol. Chem. 135, 37 (1940).

10) R.O. Wellenstein et al : Iron in clinical Medicine Univ. of Calfonia press (1958).

11）前島 豊：日本医大誌，26,987 (1959)

12）福島：血液学討議会報告，功輯 1 (1949)

13）山下泰道：日本医大誌，26，1374 (1959)

14) J. Lange : Eisen, Kupfer und EiweliB an Beispiel der Leber-Krankheiten. Georg Thiene Verlag Stuttgart.

15) A.E. Martell : Chemistry of the Metal Ckelate Compounds (1952).

16）横瀬武正：日本医大誌，24，8 (1956)

17) R.C. Crafts et al : Endocrinology, 41, 341 (1948).

18）榊原 仟: Hyaluronidase と臨床，医家蓞書 53. 医 学書院 (1953)

19) M. Ginsberg et al: J. Physiol, 123, 574 (1954).

20) H. Hopper, : Liver ; Structur and Funktion I McGraw-Hill book company, Inc. New York 131 (1957)

21) C. Smith et al : J. Clin. Invest., 32, 625 (1953).

22) G. Sayers and M.A. Sayers: Endocrinoe, 40, 265(1947).

23) J.C. Opsahl : Yale J. Biol. Med., 21, 255 (1949) :22, 115 (1950). 